\title{
ФАКТОРИ ТА НАСЛІДКИ РОЗВИТКУ ПРОФЕСІЙНОГО СТРЕСУ МЕДИЧНОГО ПЕРСОНАЛУ ОНКОЛОГІЧНОГО ВІДДІЛЕННЯ
}

\author{
А. С. Каршунова, Л. Є. Лимар \\ Тернопільський національний медичний університет \\ імені І. Я. Горбачевського МОз Украӥни
}

У статті розглянуто фактори та причини, що впливають на появу професійного стресу. Зосереджено увагу на розвитку синдрому емоційного вигорання, його суті та складових.

\section{FACTORS AND CONSEQUENCES OF DEVELOPMENT OF PROFESSIONAL STRESS OF MEDICAL STAFF IN ONCOLOGICAL DEPARTMENT}

\author{
A. S. Karshunova, L. Ye. Lymar \\ I. Horbachevsky Ternopil National Medical University
}

The article adduces the factors and causes that influence the emergence of occupational stress. The focus is on the development of emotional burnout syndrome, its nature and components.

Вступ. Професійна діяльність медичного персоналу онкологічного відділення належить до стресових напрямків медико-соціального обслуговування та пов'язана з активною міжособистісною взаємодією, постійною емоційною самовідданістю з високим рівнем відповідальності. Психоемоційне та нервове перевантаження у більшості випадків призводить до розвитку професійного стресу.

Основна частина. Актуальність зазначеної проблеми зумовлена негативними наслідками професійного стресу. Саме професійний стрес стає причиною того, що значна кількість високоосвічених працівників перебуває у пригніченому психологічному стані, залишає свої робочі місця, змінює сферу діяльності, звертається за допомогою до консультантів-психологів. Дослідники L. M. Wilkes, B. Beale, P. Hudson, Sh. Payne доводять, що працівники закладів паліативної допомоги, зазнаючи тривалого стресу на роботі, демонструють посилення станів тривоги, збільшення випадків клінічно вираженої депресії, часто навіть більш вираженої, ніж у пацієнтів [1].

Робота в онкологічному відділенні є особливою відносно професійного стресу, оскільки поєднує значну кількість факторів, що впливають на його появу [2-4]:

(С) А. С. Каршунова, Л. Є. Лимар, 2020
1. Комунікація та взаємодія з пацієнтами та членами їхньої сім'і, що включають:

- догляд за тяжкохворими людьми, повідомлення поганих новин пацієнту та його родичам;

- спілкування з онкологічними пацієнтами та членами їхніх родин, які перебувають у стресовому стані та часто проявляють негативні емоції;

- високу складність спілкування з близькими хворого в «переломні» періоди лікування (рецидив, продовження хвороби) та на термінальній стадії захворювання.

2. Характеристики онкологічної патології як соматичної нозології, які зумовлюють те, що:

- медичний персонал $\epsilon$ «свідком» фізичних та емоційних страждань хворого; складність проблем пацієнта та неможливість їх повністю вирішити (забезпечити повне одужання);

- прийняття відповідальних рішень, що суттєво впливають на тривалість та якість життя пацієнта.

3. Наявність проблеми смерті та вмирання [5].

4. Особливості організації діяльності та вимоги до професійних навичок, а саме: значне робоче перевантаження; високі кваліфікаційні вимоги; необхідність підвищення професійного рівня (курси, конференції, ознайомлення з публікаціями). 
За даними досліджень науковців П. І. Сидорова, А. В. Красильнікова, О. В. Рибіна та ін., найактуальнішими проблемами працівників онкологічних служб $\epsilon$ :

- соматичні (у значної кількості працівників через 2-3 роки з'являються симптоми різних хвороб);

- матеріальні (незадоволення матеріальним становищем, численні професійні обов'язки);

- побутові умови праці (робота в онкології, паліативних відділеннях, хоспісах часто пов'язана зі складними умовами праці, психоемоційними та фізичними навантаженнями) [6].

Наслідком хронічного професійного стресу медичного персоналу онкологічного відділення $\epsilon$ поява синдрому емоційного вигорання. Цей синдром зазвичай розцінюється як стрес-реакція у відповідь на виробничі та емоційні вимоги. Надмірна залученість людини до роботи зі зменшенням часу на сімейне життя і відпочинок викликає значне внутрішнє накопичення негативних емоцій без відповідної «розрядки» або «звільнення» від них [7].

Термін «синдром професійного вигорання» був введений у 1974 р. американським психіатром Х. Дж. Фрейденбергом для характеристики психологічного стану здорових людей, які інтенсивно спілкуються з пацієнтами, клієнтами і постійно перебувають в емоційно напруженій атмосфері під час надання професійної допомоги [7]. У Міжнародному статистичному класифікаторі захворювань та проблем, пов'язаних зі здоров'ям (International Statistical Classification of Diseases and Related Health Problems 10th Revision (ICD-10)-2015-WHO Version for; 2015), цей термін має вже діагностичний статус «Z 73.0 Вигорання, стан життєвого виснаження» [7].

Згідно з моделлю синдрому вигорання, яка була запропонована американськими науковцями Christina Maslach та Susan E. Jackson, професійне вигорання визначено як синдром емоційного виснаження, деперсоналізація і редукція особистих досягнень [7].

Синдром емоційного виснаження включає такі складові:

- емоційне виснаження розглядається як основна складова професійного вигорання та характеризується відчуттям спустошеності та втоми;

- деперсоналізація (дегуманізація) проявляється у цинічному ставленні до професійних обов'язків та пацієнтів;

- редукція особистих досягнень (відчуття професійної компетентності) полягає або в тенденції до негативного оцінювання себе, своїх професійних досягнень та успіхів, або у нівелюванні особистої гідності, обмеженні своїх можливостей, обов'язків щодо інших тощо [7].

Серед медичних працівників онкологічного профілю високий рівень емоційного виснаження визначається у 15-25 \% працівників, деперсоналізація в 4-15\%, заниження оцінки особистісних досягнень у $30-65 \%$ [8].

За результатами дослідження І. Коваля, провідними ознаками емоційного вигорання в лікарів-онкологів були відчуття емоційної спустошеності, тривога, зниження настрою, розширення сфери економії емоцій, психоемоційна та особистісна відстороненість, зниження продуктивності праці, незадоволення собою, дистанціювання від пацієнтів і колег [9].

Необхідно додати, що негативні наслідки синдрому емоційного вигорання проявляються у всіх учасників лікувальної взаємодії. У медиків - зниженням продуктивності праці, низькою самооцінкою професійної компетентності, погіршенням фізичного та психічного здоров'я, зміною діяльності, психосоціальними труднощами. У пацієнтів та їхніх близьких - зниженням якості медичної допомоги, порушенням прихильності до терапії, негативним і недовірливим ставленням до медицини, конфліктами з медичним персоналом. Для системи охорони здоров'я - погіршенням якості медичної допомоги, зниженням показників здоров'я населення, відтоком (звільненнями) кваліфікованих працівників, негативним ставленням до медицини загалом [9].

Медичний персонал онкологічного відділення, зокрема середній, перебуває в умовах хронічного професійного стресу. Це зумовлено тим, що під час виконання професійних обов'язків медики постійно опікуються людьми, які перебувають у тяжкому фізичному та психічному стані. Спілкування з хворими та їхніми рідними, перебування в колі складних людських проблем, негативних емоцій страху, болю, а також відчуття відповідальності за життя та одужання пацієнтів, вимоги високої компетентності, без належного відпочинку та «розрядки» - це все призводить до розвитку синдрому емоційного вигорання. Ефективні методи подолання синдрому емоційного вигорання мають стати важливим напрямком сучасних досліджень.

Висновки. Медичний персонал онкологічного відділення перебуває в умовах хронічного професійного стресу. Урахування ризиків виникнення цього синдрому ще на етапі підготовки фахівців із медичною освітою $є$ визначальним. 


\section{СПИСОК ЛІТЕРАТУРИ}

1. Wilkes L. M. Palliative care at home: Stress for nurses in urban and rural New South Wales, Australia / L. M. Wilkes, B. Beale // International Journal of Nursing Practice. - 2008.

2. Russell K. Perceptions of burnout, its prevention, and its effect on patient care as described by oncology nurses in the hospital setting / K. Russell // Oncol. Nurs. Forum. 2016. - Vol. 43 (1). - P. 103-109.

3. Strategies to promote coping and resilience in oncology and palliative care nurses caring for adult patients with malignancy: a comprehensive systematic review / L. Gillman, J. Adams, R. Kovac [et al.] // JBI Database System Rev. Implement. Rep. - 2015. - Vol. 13 (5). - P. 31-204.

4. Vasilyeva G. Y. The effectiveness of correction emotional burnout in oncologists as one of the indicators of quality of care for patients with cancer / G. Y. Vasilyeva // Medical Perspectives. - 2010. - Vol. 15 (1). - P. 81-83.

5. Дмитришина Н. А. Професійний стрес та задоволеність роботою серед працівників закладів паліативної допомоги / Н. А. Дмитришина // Соціальна політика щодо невиліковно хворих : матеріали Всеукраїнської науковопрактичної конференції (15-16 березня 2012 р.). - К. : Університет «Україна», 2012. - С. 44-53.

6. Деструктивный профессиогенез в онкологии / П. И. Сидоров, А. В. Красильников, И. А. Новикова, А. А. Кузнецова // Экология человека. - 2009. - № 5. C. 16-24.

7. Синдром вигорання : клінічні випробування в Україні [навчання та тренінг] [Електронний ресурс]. - Режим доступу : https://crupp.org/uk/sindrom-vigorannya/.

8. Psycho-Oncology / J. C. Holland, W. S. Breitbart, P. B. Jacobsen [et al.] - Oxford : Oxford University press, 2015.

9. Коваль І. Синдром емоційного вигорання в лікарів онкологічного профілю та шляхи його подолання [Текст] / І. Коваль // Нейро News: психоневрологія та нейропсихіатрія. - 2018. - № 1. - С. 35-37.

Отримано 24.12.19 